\author{
Л.Л. Мехришвили* \\ В.П. Карпов ${ }^{* *}$ \\ Международная научная конференция \\ «Тюменская область: историческая \\ ретроспектива, реалии настоящего, \\ контуры будущего»
}

\author{
DOI: 10.31518/2618-9100-2019-5-17
}

L.L. Mehrishvili* V.P. Karpov ${ }^{* *}$

\section{International Scientific Conference "Tyumen Region: Historical Retrospective, Realities of the Present, Contours of the Future”}

DOI: 10.31518/2618-9100-2019-5-17

How to cite:

Mehrishvili L.L., Karpov V.P. International

Мехришвили Л.Л., Карпов В.П. Международная научная конференция «Тюменская область: Scientific Conference “Tyumen Region: Historical историческая ретроспектива, реалии настоящего, Retrospective, Realities of the Present, Contours of the контуры будущего» // Исторический курьер. 2019. Future” // Historical Courier, 2019, No 5 (7), pp. 196 № 5 (7). C. 196-198. URL: http://istkurier.ru/data/2019/ 198. [Available online:] http://istkurier.ru/data/ ISTKURIER-2019-5-17.pdf

14 августа 2019 г. Тюменской области исполнилось 75 лет (1944-2019 гг.). Юбилейной дате и была посвящена международная научная конференция «Тюменская область: историческая ретроспектива, реалии настоящего, контуры будущего», прошедшая 20-21 сентября 2019 г. на площадках Тюмени и Тобольска. Главная тема конференции: «От поиска вариантов экономического развития - к энергетическому лидерству в стране». Ученые попытались выяснить, как тихая в послевоенные пятилетки заводь советской экономики превратилась к середине 1970-хгг. в главную топливную базу страны. Обсуждались проблемы прошлого, настоящего и будущего территории. Историки, экономисты, геологи и представители других наук особое место уделили вопросам развития нефтегазового тюменского Севера, проблемам геологии, что нашло отражение в резолюции, принятой по итогам форума.

Организаторы конференции (Тюменский индустриальный университет совместно с Тюменской областной думой, Правительством Тюменской области, Тобольским педагогическим институтом им. Д.И. Менделеева, Тюменским государственным медицинским университетом, Тюменским отделением Российского исторического общества) сформулировали ее цель - обобщение и осмысление исторического опыта развития региона.

После конкурсного отбора в программу форума были включены 106 докладов и сообщений, поступивших от 142 авторов. Участники конференции представляли Москву, Екатеринбург, Новосибирск, Тюмень, Салехард, Ханты-Мансийск, Сургут, Нижневартовск и другие города Российской Федерации, а также университеты и колледжи Казахстана, Кыргызстана, США и Франции. Свои научные разработки представили ученые из Института российской истории РАН (Москва), Института истории Сибирского отделения РАН (Новосибирск), Института истории и археологии Уральского отделения РАН (Екатеринбург), Тюменского научного центра Сибирского отделения РАН (ТюмНЦ СО РАН), Научного центра изучения Арктики (Салехард), Западно-Сибирского филиала Федерального научно-исследовательского социологического центра РАН, музейные работники из Тюмени, Сургута и Нижневартовска.

\footnotetext{
* Мехришвили Ламара Ленгизовна, доктор социологических наук, Тюменский индустриальный университет (Тюмень, Россия), e-mail: lamara_m@inbox.ru

Mehrishvili Lamara L., Doctor of Sociological Sciences, Tyumen Industrial University (Tyumen, Russia), e-mail: lamara_m@inbox.ru

${ }^{* *}$ Карпов Виктор Петрович, доктор исторических наук, доцент, Тюменский индустриальный университет (Тюмень, Россия), e-mail: 7654321.58@mail.ru

Karpov Victor P., Doctor of Historical Sciences, Tyumen Industrial University (Tyumen, Russia), e-mail: 7654321.58@mail.ru
} 
На пленарном заседании с научными докладами выступили ученые РФ и зарубежья: доктор социологических наук, профессор Ю.М. Конев (тема доклада: «Ретроспектива становления Тюменской области как субъекта Российской Федерации»); заведующий кафедрой истории РГУ нефти и газа им. И.М. Губкина (Москва), доктор исторических наук В.В. Калинов («О стратегиях освоения Западной Сибири в послевоенные десятилетия и их реализации»); профессор из университета г. Руан (Франция) Иветт Ваге («Пространственновременная эволюция городов Арктики»); профессор ТИУ, доктор экономических наук В.В. Елгин («Арктический вектор индустриального и инфраструктурного развития Тюменской области»); профессор ТИУ, доктор социологических наук А.Н. Силин («Тюменская область как плацдарм социально-пространственной трансформации Российской Арктики»); другие титулованные ученые-североведы.

В первый день в рамках научного форума работали четыре площадки. Из 14 докладов секции «Западно-Сибирский нефтегазовый комплекс: создание и развитие» особый интерес вызвали выступления, посвященные персоналиям: «Ким Анатолий Индекович - один из первооткрывателей большой нефти Тюменской области» (доклад сургутских историков В.А. Араслановой и Н.Н. Рашевской); «От рабочего до “нефтяного маршала”: Виктор Иванович Муравленко и Западно-Сибирский нефтегазовый комплекс» (доклад профессора ТИУ, доктора технических наук С.Н. Бастрикова). В обсуждении выступлений приняли участие как историки, так и ветераны геологоразведки. Почетный гость конференции, заслуженный геолог РФ, доктор геолого-минералогических наук А.М. Брехунцов рассказал о своих встречах с А.И. Кимом, о совместной трудовой деятельности.

Несмотря на широкий спектр проблем, заслушанных на секции «История Тюменского края» (экономика, культура, политика, война, тыл, повседневность труда и быта) и большой временной горизонт (от истории древнего заселения Тазовского Заполярья (доктор исторических наук, профессор А.А. Ткачев) до места Ямала в пространстве современной цивилизации (доктор исторических наук, проф. А.В. Трофимов), большинство выступлений вызвали заинтересованное обсуждение. Такое внимание к докладам объясняется как недостаточной изученностью многих проблем, так и тем, что в зале собрались профессиональные историки. Впрочем, не только историков, но и представителей других профессий интересовало, например, как посчитать строителей Тюменской области, если на Тюменском Севере были задействованы строительные коллективы практически из всех союзных республик, а буровые бригады и бригады капитального ремонта скважин (это строители?) летали вахтами в нефтегазодобывающие районы из 320 городов СССР?

Обсуждение проблем развития Тюменской области на современном этапе проходило на секции «Социокультурное развитие Тюменской области». Большинство докладов было посвящено проблемам защиты природы как собственно Тюменской области, так и северных территорий региона - Югры и Ямала. Это свидетельствует о росте интереса исследователей к экологической истории, которая в XXI в. превращается в самостоятельное направление исторической науки.

На площадке Тюменского государственного медицинского университета проходило обсуждение проблем становления системы здравоохранения в Тюменской области. Авторами докладов были профессора и доценты, заведующие кафедрами и ординаторы ведущего в регионе медицинского научного и образовательного центра. В выступлениях поднимались вопросы развития медицины в широком диапазоне: от общероссийского (советского) до поселкового. Обратились ученые и к проблемам охраны здоровья человека на Севере.

Работа второго дня конференции была организована и проведена на базе Тобольского педагогического института им. Д.И. Менделеева. Темами круглого стола «Освоение Тюменского сектора Арктики» стали как прошлое и настоящее в развитии нефтегазовых районов Тюменского Крайнего Севера, так и вопросы дальнейшего обустройства территории. Участники заседания были единодушны в выводе: северные и арктические 
территории «большой» Тюменской области обладают огромным потенциалом разработки их природных богатств, развития экономики и благоустройства жизни людей.

Особый интерес вызвало сообщение заслуженного геолога РФ, доктора геологоминералогических наук В.Н. Бородкина, который в своем выступлении ““Трубки взрыва” на шельфе Карского моря и Ямальском полуострове» раскрыл загадку появления глубоких воронок на территории Ямала. Ученый не только подробно обосновал природу данного явления, но и поделился предположениями о возможностях его использования. По словам докладчика, такие гигантские провалы вызваны выходом на поверхность больших объемов природного газа, поднимающегося из больших залежей газовых гидратов под влиянием многих факторов, в том числе благодаря глобальному потеплению. На шельфе в Карском море такие выходы газа происходят в гораздо большем количестве. «Порой они подобны извержениям вулканов, только природа этих кратеров несколько другая - на поверхность Земли или под толщей воды вырывается не раскаленная магма, а холодный газ», - отметил ученый. Важность этого явления в том, что оно является безусловным маркером нахождения на значительной глубине больших залежей природного газа.

Не остались без обсуждения и сообщения членов Студенческого научного общества (CHO) «Arctic Research Community - Арктическое научное сообщество» (ARC) A.В. Широких и Г.С. Яркова. Первый рассказал об итогах экспедиции «Плавучий Арктический университет» в июне-июле 2019 г. (Маршрут Архангельск - разрез «Кольский меридиан» - Шпицберген - Лонгйир - Пирамида - Ню-Олесунн - Ню-Лондон Архангельск), второй - об итогах поездки в Арктическую школу Харбинского технологического института летом этого же года.

В ходе заседания круглого стола известный тобольский меценат и историк Григорий Елфимов презентовал четырехтомное издание, посвященное истории Северного морского пути.

Материалы докладов и выступлений участников конференции и дискуссии на заседаниях секций и круглого стола подтвердили, что диалог представителей различных наук в изучении процессов, происходивших в прошлом и идущих сегодня в Тюменской области, необходимо продолжить. Данное сотрудничество является важным условием успешного развития как региона, так и страны в целом.

Статья поступила в редакцию 01.10.2019 г. 